\title{
Three new species of Paraboea
}

\section{(Gesneriaceae) from limestone karsts of China based on morphological and molecular evidence}

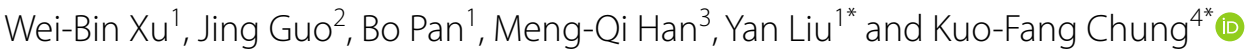

\begin{abstract}
Background: The limestone karsts of Southeast Asia and South China are a major biodiversity hotspot of global terrestrial biomes. With more than 130 described species, Paraboea has become one of the most characteristic plant groups in the Southeast Asian limestone flora. During the course of extensive field work on the limestone formations of southern and southwestern China, three unknown species of Paraboea were collected.
\end{abstract}

Results: Molecular phylogenetic analyses based on nuclear ITS and chloroplast trnL-F sequences strongly confirm the placements of the three new species in Paraboea sensu Puglisi et al. (Taxon 65:277-292. https://doi. org/10.12705/652.5, 2016). Moreover, these three novelties can be distinguished from known Paraboea species with distinct morphological characters, further supporting their recognition as new species.

Conclusions: With the support of detailed morphological studies and molecular phylogenetic analyses, Paraboea dushanensis, P. sinovietnamica and P. xiangguiensis are recognized as three species new to science.

Keywords: Limestone flora, Loxocarpinae, Paraboea dushanensis, Paraboea sinovietnamica, Paraboea xiangguiensis, Sino-Vietnamese limestone karsts (SVLK)

\section{Background}

As currently circumscribed, the Asian gesneriad genus Paraboea (C.B.Clarke) Ridl. comprises ca. 130 species of rosulate or caulescent herbs characterized by the abaxially matted leaves with densely interwoven indumentum and flowers with flat-faced to shortly campanulate corolla and non-erect anthers (Middleton et al. 2010; Puglisi et al. 2016). A majority of Paraboea species are lithophytes on limestone substrates, distributed in South China, northeastern India and the eastern Himalayas, Indochina, and

\footnotetext{
*Correspondence: gxibly@163.com; bochung@gate.sinica.edu.tw ${ }^{1}$ Guangxi Key Laboratory of Plant Conservation and Restoration Ecology in Karst Terrain, Guangxi Institute of Botany, Guangxi Zhuangzu Autonomous Region and Chinese Academy of Sciences, Guilin 541006, China

${ }^{4}$ Research Museum and Herbarium (HAST), Biodiversity Research Center, Academia Sinica, Taipei 11529, Taiwan

Full list of author information is available at the end of the article
}

Malesia as far east as Sulawesi (Middleton et al. 2010). Since the last major revision by Xu et al. (2008) in which 89 species and 5 varieties were recognized, Paraboea has been expanded to include the ca. 20 species of Phylloboea Benth. and Trisepalum C.B.Clarke (Puglisi et al. 2011), with the reduction of five taxa constituting the new genus Middletonia C.Puglisi (Puglisi et al. 2016). More than 30 new species have also been described since the revision by Xu et al. (2008), almost all narrowly distributed endemic from limestone karsts (Chen et al. 2008, 2012; Kiew 2010; Triboun and Middleton 2012, 2015; Xu et al. 2012a; Triboun 2013; Wen et al. 2013; Puglisi et al. 2015; Guo et al. 2016; Wen and Wei 2016). Because a great proportion of Asian limestone karsts remain unexplored or underexplored, it is fully expected that additional new species of Paraboea will be unearthed given that further field investigations and herbarium work are conducted (Puglisi et al. 2015). 
Sino-Vietnamese limestone karsts (SVLK) are vast terrains striding across the border between China and Vietnam (Xu et al. 2012b; Chung et al. 2014), renowned for their spectacular landscape and rich biodiversity (Myers et al. 2000; Clements et al. 2006; Hou et al. 2010; LópezPujol et al. 2011). Botanically, the SVLK are home to a myriad of species-rich genera with narrowly endemic entities (Chung et al. 2014) such as Aspidistra KerGawler (e.g., Liu et al. 2011, 2016), Begonia L. (e.g., Peng et al. 2014, 2015), Elatostema Forster \& Forster (e.g., Wei et al. 2011), Impatiens L. (e.g., Tan et al. 2015; Yu et al. 2015), Polystichum Roth (He and Zhang 2011; Zhang and He 2011), and several genera of Gesneriaceae (Wei 2010; $\mathrm{Xu}$ et al. 2012b, 2014; Guo et al. 2015) including Paraboea (Xu et al. 2012a; Guo et al. 2016).

During the course of extensive floristic surveys in limestone karsts of southern and southwestern China in recent years, we collected three species of Paraboea with spectacular flowers and/or fruits not known previously. After consulting the relevant literature (Burtt 1984; Wang et al. 1990, 1998; Li and Wang 2004; Chen et al. 2008, 2012; Xu et al. 2008, 2012a; Kiew 2010; Triboun and Middleton 2012; Wen et al. 2013; Guo et al. 2016; Wen and Wei 2016), as well as herbarium specimens of E, GXMI, HITBC, IBK, IBSC, KUN, and PE (herbarium acronyms according to Index Herbariorum; Thiers 2017), they were identified as three new species of Paraboea based on detailed examination of salient morphological and anatomical features and molecular phylogenetic analyses.

\section{Methods}

\section{Taxon sampling and DNA sequencing}

For phylogenetic analyses, a majority of species of Paraboea available in GenBank were used, with nine additional species endemic to China sampled. A total of 83 accessions representing 67 species of Paraboea were included in this study. Based on Puglisi et al. (2016), two species of Ornithoboea Parish ex C.B.Clarke and three species of Middletonia C.Puglisi were chosen as outgroups. Species, voucher information, and NCBI accession numbers are listed in Additional file 1. Two molecular markers, including the nuclear ITS (internal transcribed spacer) and the chloroplast trnL-F intronspacer region $(\operatorname{trn} L-F)$, were used in this study. Total genomic DNA was extracted from silica gel-dried leaf materials using the CTAB protocol (Doyle and Doyle 1987). The primers ITS-4 and ITS-5 (Möller and Cronk 1997) were used to amplify and sequence the ITS region. The primers trnL-F $e$ and $f$ (Taberlet et al. 1991) were used to amplify and sequence the cp DNA region based on the PCR procedures outlined in Guo et al. (2016). The PCR products were purified using the Tian quick Midi Purification Kit (TianGen Biotech, Beijing, China) and directly sequenced. Sequencing reactions were performed using the ABI Prism Bigdye Terminator Cycle Sequencing Kit (Applied Biosystems, Foster City, California, USA). Sequences were analyzed using an ABI 3730 DNA Sequencer. The program Sequencher 5.0 (Gene Codes Co., Ann Arbor, Michigan, USA) was used to evaluate chromatograms for base confirmation and to edit contiguous sequences. Sequences were initially aligned using MUSCLE 3.8.31 (Edgar 2004), followed by manual adjustments in Geneious 9.1.2 (http://www.geneious. com, Kearse et al. 2012).

\section{Phylogenetic analyses}

The phylogenetic analyses were conducted based on maximum likelihood (ML) and Bayesian inference (BI) methods for the individual locus datasets (ITS/trnL-F) and combined dataset (ITS-trnL-F), using RAxML v7.0.4 (Stamatakis et al. 2008) and MrBayes v3.3.5 (Ronquist et al. 2012), respectively. The model GTR $+\Gamma$ was selected as the optimal model for both DNA regions based on the Akaike Information Criterion via jModeltest v2.1.4 (Posada 2008). For ML analyses, node support was estimated with nonparametric bootstrap (1000 replicates) following a thorough search for the best ML tree. For BI analyses, four runs of Metropolis-coupled Markov chain Monte Carlo (MCMCMC) analyses were conducted with one tree sampled for every 2000 generations over 20 million generations, starting with a random tree. Analyses were run until the average standard deviation of the split frequencies approached 0.01 , indicating that two runs converged to a stationary distribution. The first $25 \%$ of sampled trees corresponding to the burn-in period was discarded, and the remaining trees were used to construct a majority-rule consensus tree. We used bootstrap support $(\mathrm{BS}) \geq 70 \%$ and posterior probability $(\mathrm{PP}) \geq 0.95$ as the thresholds for strongly supported clades (Wang et al. 2014). To investigate congruence between the nuclear and chloroplast genomes, topologies of the ITS and trnL$F$ datasets of both ML and BI analyses were compared. Because a majority of clades with $\mathrm{BS} \geq 70 \%$ and $\mathrm{PP} \geq 0.95$ were congruent without significant conflicts, the concatenated dataset was presented for further discussion.

\section{Results and discussion}

The concatenated DNA matrix (78 ITS sequences and 81 trnL-F sequences) had a length of 1780 aligned characters (ITS: $812 \mathrm{bp}$, trnL-F: $968 \mathrm{bp}$ ), of which 645 (ITS: $454 \mathrm{bp}, \operatorname{trnL}-F: 191 \mathrm{bp}$ ) are variable and 415 (ITS: $332 \mathrm{bp}$, trnL-F: $83 \mathrm{bp}$ ) are parsimony informative. The best ML phylogram with bootstrap (BS) supports and posterior probability (PP) values of Bayesian analyses is depicted in Fig. 1. The phylogenetic relationships of the concatenated matrix are congruent with those reported in Puglisi et al. 
(2011, 2016). Samples of the three new species (Paraboea dushanensis, P. sinovietnamica and P. xiangguiensis) are shown as distinct clades grouped within Paraboea sensu Puglisi et al. (2016) with strongest support values ( $\mathrm{BS}=100 \%, \mathrm{PP}=1.00)$, ascertaining their recognition as distinct species of Paraboea. Multiple samples identified as Paraboea dushanensis, P. xiangguiensis, and $P$. sinovietnamica are all monophyletic (BS $=98,100,70 \%$, $\mathrm{PP}=1.00,1.00,0.96$ ), and each of these three new species is placed as sister group of its morphologically most similar congener [i.e., P. velutina (W.T.Wang \& C.Z.Gao) B.L.Burtt, Paraboea crassifolia (Hemsl.) B.L.Burtt, P. guilinensis L.Xu \& Y.G.Wei, and P. sinensis (Oliv.) B.L.Burtt] with strong support (Fig. 1).

\section{Conclusions}

\section{Taxonomic treatment}

Paraboea dushanensis W.B.Xu \& M.Q.Han, sp. nov. 独山蛛毛茾苔 (Figs. 2, 3)

Diagnosis: Paraboea dushanensis is similar to P. velutina (W.T.Wang \& C.Z.Gao) B.L.Burtt, but it can be distinguished by having 6-13 leaves, congested at the apex of the rhizome (vs. many leaves spirally arranged, crowded near branch apex), the large leaf blade $4-8 \times 0.7-1.5 \mathrm{~cm}$ (vs. $0.9-2.3 \times 0.4-1.0 \mathrm{~cm}$ ), the calyx lobes $3.5-5 \times 1.0-$ $1.2 \mathrm{~mm}$, with ferrugineous matted indumentum outside (vs. 1.0-1.2 × $0.3 \mathrm{~mm}$, outside glandular-puberulent), the corolla 1.1-1.6 cm long, purple-blue, outside glabrous (vs. 4-5 cm long, white, outside glandular-puberulent).

Type: CHINA. Guizhou: Dushan County, Xiasi Town, $920 \mathrm{~m}, 25^{\circ} 27^{\prime} \mathrm{N}, 107^{\circ} 30^{\prime} \mathrm{E}, 26$ May 2015, Wei-Bin Xu et al. 12319 (holotype IBK, isotypes PE, HAST).

Perennial herbs: Rhizomes subterete, 4-10 cm long, 2-6 $\mathrm{mm}$ in diameter, branched at the apex of rhizome. Leaves 6-13, congested at the apex of rhizome, subsessile, petiole $1.5-3.5 \mathrm{~mm}$ long, ca. $1.5 \mathrm{~mm}$ in diameter, covered with grayish to brownish matted indumentum, leaf blade 4-8 $\times 0.7-1.5 \mathrm{~cm}, 3-6$ times as long as wide, oblanceolate, rarely oblong, leathery, bases cuneate to attenuate, margins crenate to shallowly repand, apices obtuse to subround, upper leaf surfaces covered with arachnoid indumentum when young, but glabrescent at maturity, lower leaf surfaces with ferrugineous matted indumentum, lateral veins $5-8$ on each side of midrib, impressed adaxially and prominent abaxially, tertiary venation conspicuously reticulate on the upper and lower leaf surface. Inflorescences cymose, axillary, 1 (rarely 2)-branched, 1-5-flowered; peduncles $3-5 \mathrm{~cm}$ long, $0.8-1 \mathrm{~mm}$ in diameter, covered with ferrugineous matted indumentum; bracts 2 , opposite, $3-5 \times 1-1.5 \mathrm{~mm}$, linear-lanceolate, margins entire, apices acute, with ferrugineous matted indumentum outside and glabrous inside; pedicels $0.6-1.5 \mathrm{~cm}$ long, ca. $0.7 \mathrm{~mm}$ in diameter, covered with ferrugineous matted indumentum. Calyx 3.5-5 mm long, 5-parted nearly to the base, lobes linearlanceolate, $1.0-1.2 \mathrm{~mm}$ wide, with ferrugineous matted indumentum outside and glabrous inside, margins entire. Corolla 1.1-1.6 cm long, purple-blue, outside and inside glabrous; tube 6-9 $\mathrm{mm}$ long, 5-8 $\mathrm{mm}$ in diameter at the mouth; the limb distinctly 2-lipped, adaxial lip 2-lobed to near base, lobes broadly ovate, 4-5 $\times$ ca. $4 \mathrm{~mm}$, abaxial lip 3-lobed to over middle, lobes oblong, 5-6 $\times$ 4-5 mm. Stamens 2, adnate to the corolla base; filaments 4-6 mm long, yellow, glabrous; anthers elliptic, ca. $2.5 \mathrm{~mm}$ long; staminodes 3 , glabrous, lateral ones 2.5-3 $\mathrm{mm}$ long, adnate to the corolla tube base; middle one $2-2.5 \mathrm{~mm}$ long, adnate to the corolla tube base. Pistil glabrous; ovary 5-6.5 mm long, ca. $1.5 \mathrm{~mm}$ in diameter, style 6-9 mm long, stigma slightly capitate. Capsule not twisted, 1.2-3.1 cm long, ca. $3 \mathrm{~mm}$ in diameter, glabrous.

Distribution, habitat and ecology: Paraboea dushanensis is only found at the type locality on limestone substrate (Fig. 8), and only one population has so far been identified by us during field investigations in 2015. Paraboea dushanensis grows on rock faces of the limestone karst, at an elevation between 900 and $960 \mathrm{~m}$.

Phenology: This new species had been observed in flower from May to June, and fruit from July to August.

Etymology: The specific epithet is derived from the type locality, Dushan County, Southern Guizhou Province.

Notes: Paraboea dushanensis is most similar to P. velutina (Fig. 9a, b) in the habit and the leaf blade shape, but it can be distinguished from the latter by many leaf characters (see Diagnosis). Paraboea dushanensis is also similar to Paraboea crassifolia (Hemsl.) B.L.Burtt, but differs in the obvious subterete rhizomes, the branching at the apex of rhizome (vs. rhizomes very unobvious, rosulate), the leaf blade oblanceolate, rarely oblong, 4-8 $\times 0.7-1.5 \mathrm{~cm}, 3-6$ times as long as wide, (vs. obovate, $3-16 \times 1.5-5 \mathrm{~cm}, 2-3$ times as long as wide), tertiary venation conspicuously reticulate on the upper leaf surface (vs. smooth on the upper leaf surface), calyx 3.5-5 mm long (vs. $2 \mathrm{~mm}$ long), capsule not twisted (vs. spirally twisted). Phylogenetic analyses revealed that these three species are closely related and yet considerably different from each other, supporting the recognition of $P$. dushanensis as a new species.

Additional specimens examined (paratypes): CHINA. Guizhou: Dushan County, Xiasi Town. 920 m, 26 May 2015, Wei-Bin Xu et al. 12320 (IBK); ibid., Wei-Bin Xu et al. 12321 (IBK), 17 May 2015, Meng-Qi Han E JinQuan Huang HMQ318 (IBK). 


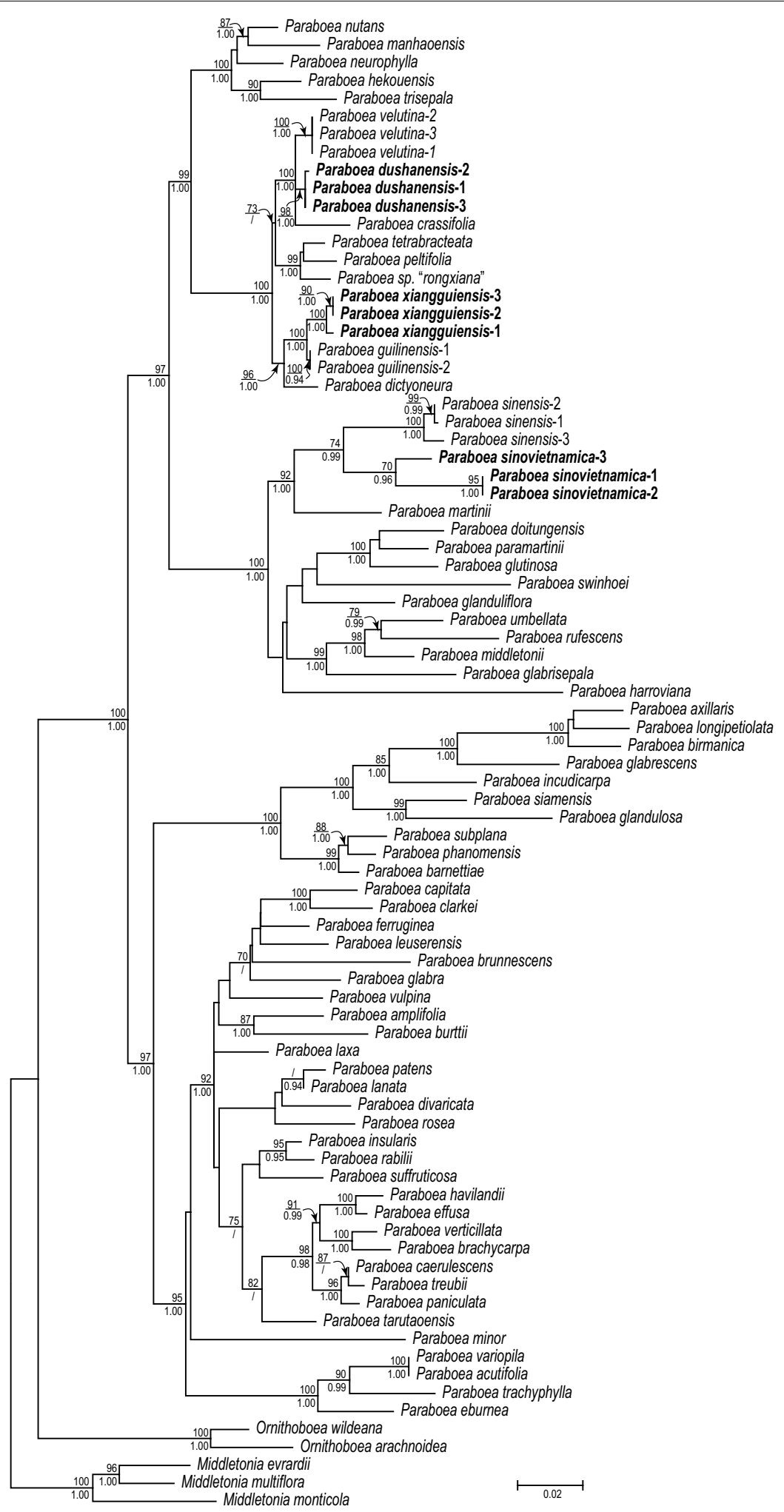

Fig. 1 The best ML tree from the analyses of the combined ITS and chloroplast trnL-F regions. ML bootstrap support values (> 70\%) and Bayesian posterior probability $>0.90$ are shown above and below the branch around the corresponding node. The three new species are highlighted in bold 


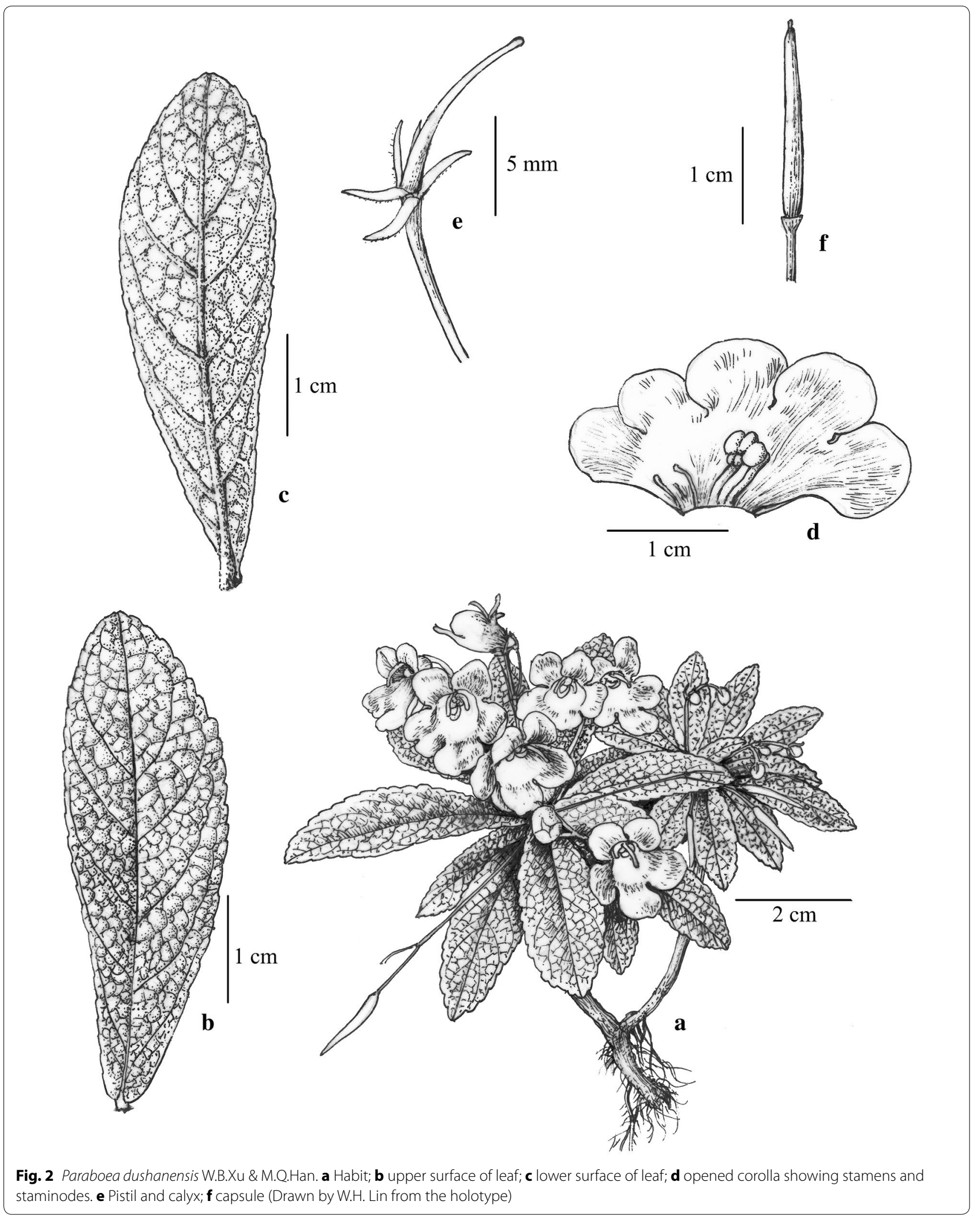



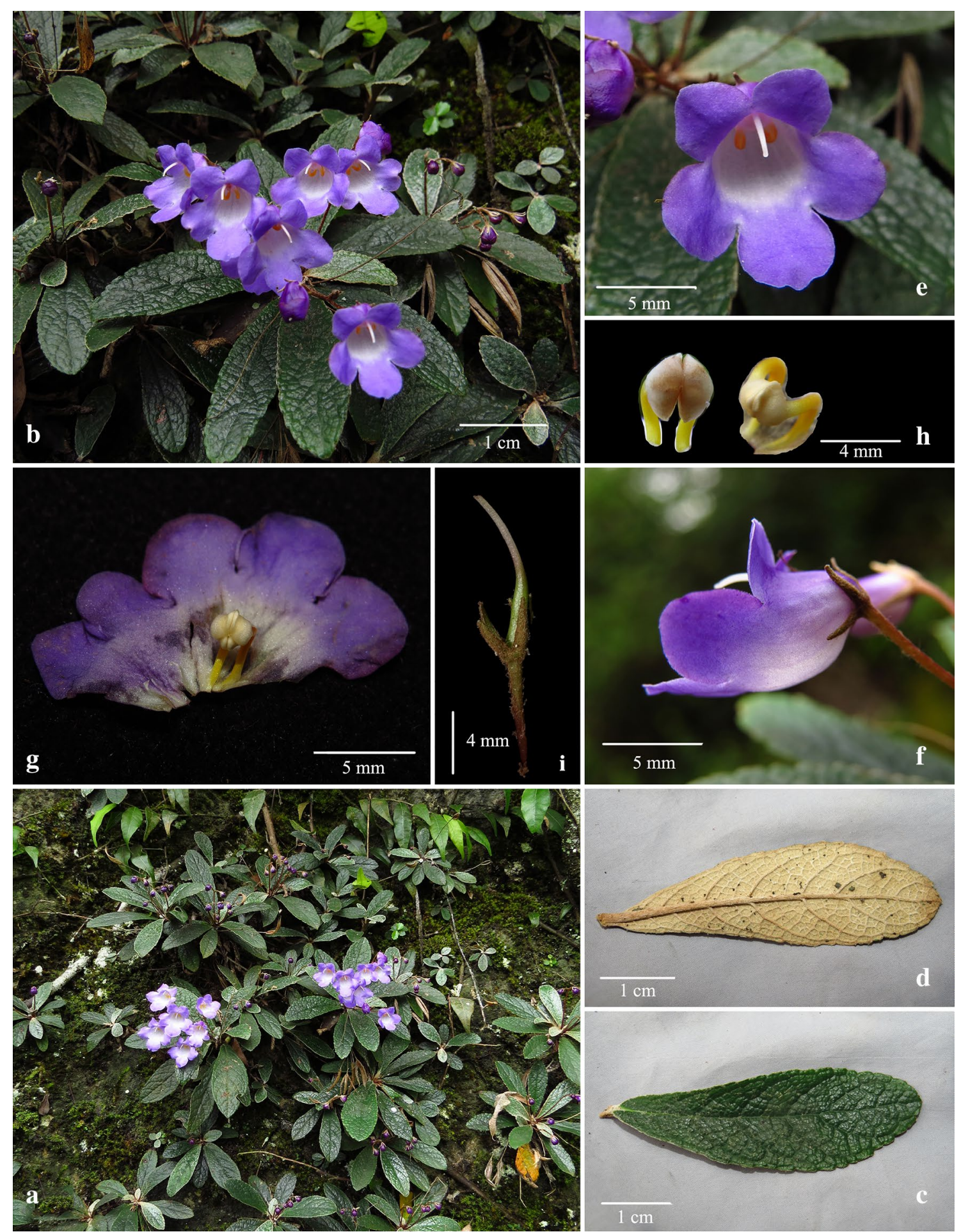

Fig. 3 Paraboea dushanensis W.B.Xu \& M.Q.Han. a Habitat; b habit; c upper surface of leaf; d lower surface of leaf; e flower face view; $\mathbf{f}$ flower side view; $\mathbf{g}$ opened corolla showing stamens and staminodes; $\mathbf{h}$ stamens; $\mathbf{i}$ pistil and calyx 


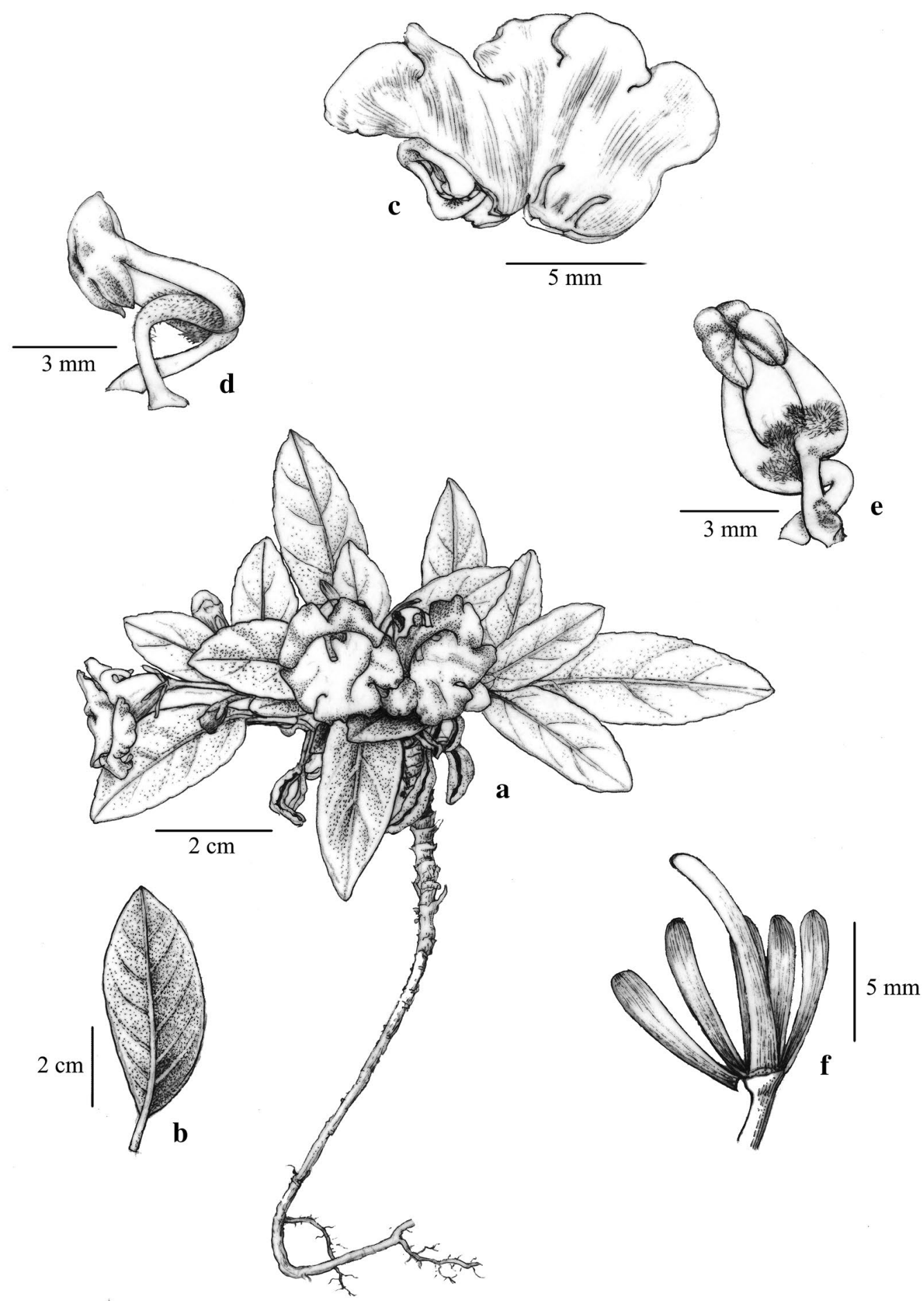

Fig. 4 Paraboea sinovietnamica W.B.Xu \& J.Guo. a Habit; b lower surface of leaf; c opened corolla showing stamens and staminodes; $\mathbf{d}$ stamens side view; e stamens face view; $\mathbf{f}$ pistil and calyx (Drawn by W.H. Lin from the holotype)

Paraboea sinovietnamica W.B.Xu \& J.Guo, sp. nov. 中越蛛毛苣苔 (Figs. 4, 5)

Diagnosis: Paraboea sinovietnamica resembles $P$. sinensis (Oliv.) B.L.Burtt in the corolla shape, but differs in being a smaller herb (vs. herb to subshrub, stem to $1.5 \mathrm{~m}$ high), the leaf blade thickly papery to thinly leathery, $2.5-6 \times 0.8-2.0 \mathrm{~cm}$ (vs. papery, $5.5-26 \times 2-10 \mathrm{~cm}$ ), the cymes, $1-3$-flowered (vs. 10 

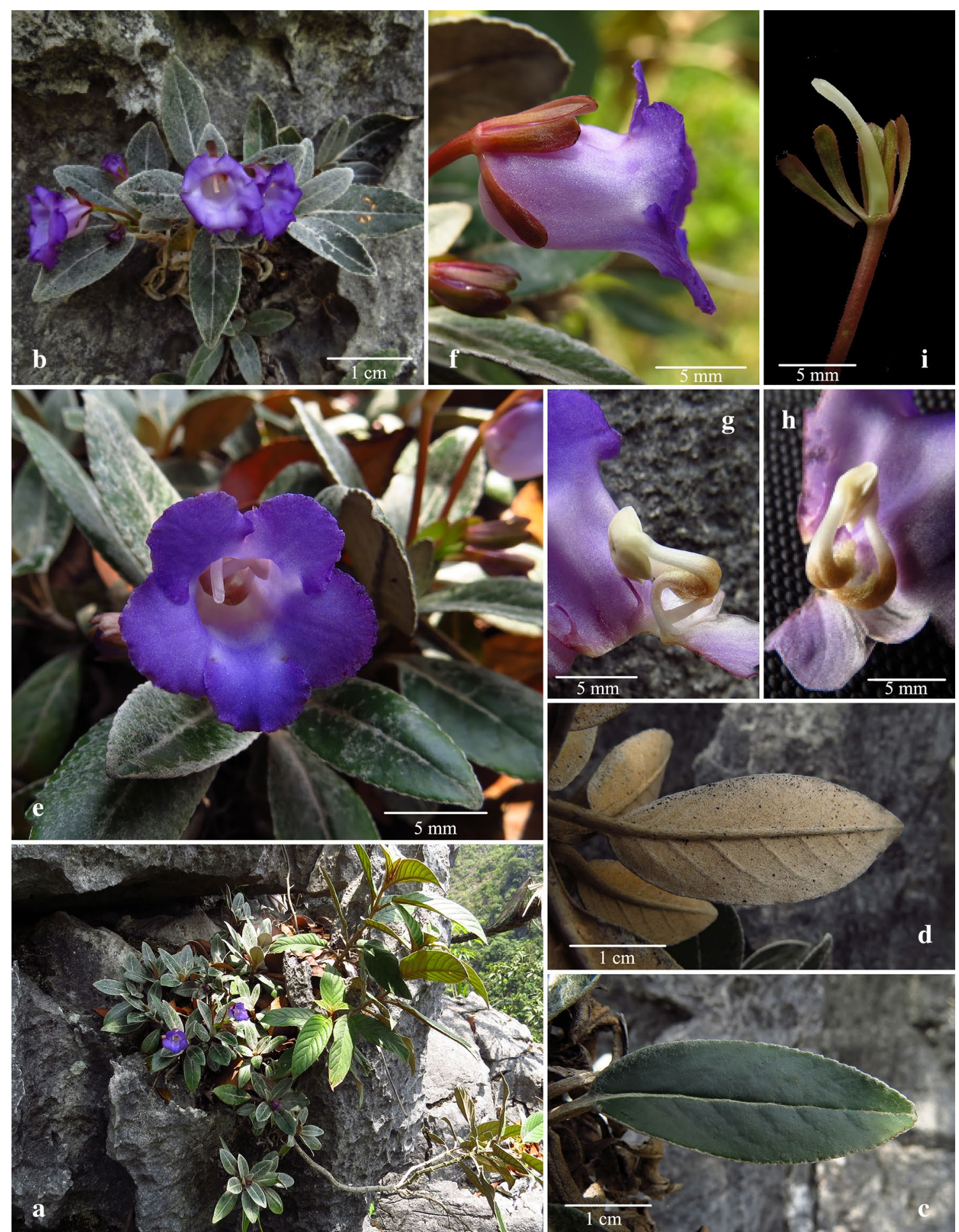

Fig. 5 Paraboea sinovietnamica W.B.Xu \& J.Guo. a Habitat; b habit; $\mathbf{c}$ upper surface of leaf; d lower surface of leaf; e flowers face view; $\mathbf{f}$ flowers side view; $\mathbf{g}$ stamens side view; $\mathbf{h}$ stamens face view; i pistil and calyx

to more flowered), the peduncle $1-3 \mathrm{~cm}$ long, glabrous (vs. 2.5-6 cm long, brown-pannose), the bracts oblong to oblong-spathulate, $4-5 \times 2-3 \mathrm{~mm}$, (vs. suborbicular to broadly ovate, $10-15 \times 8-12 \mathrm{~mm})$, the filaments bearded at the middle (vs. pubescent to glabrous). 


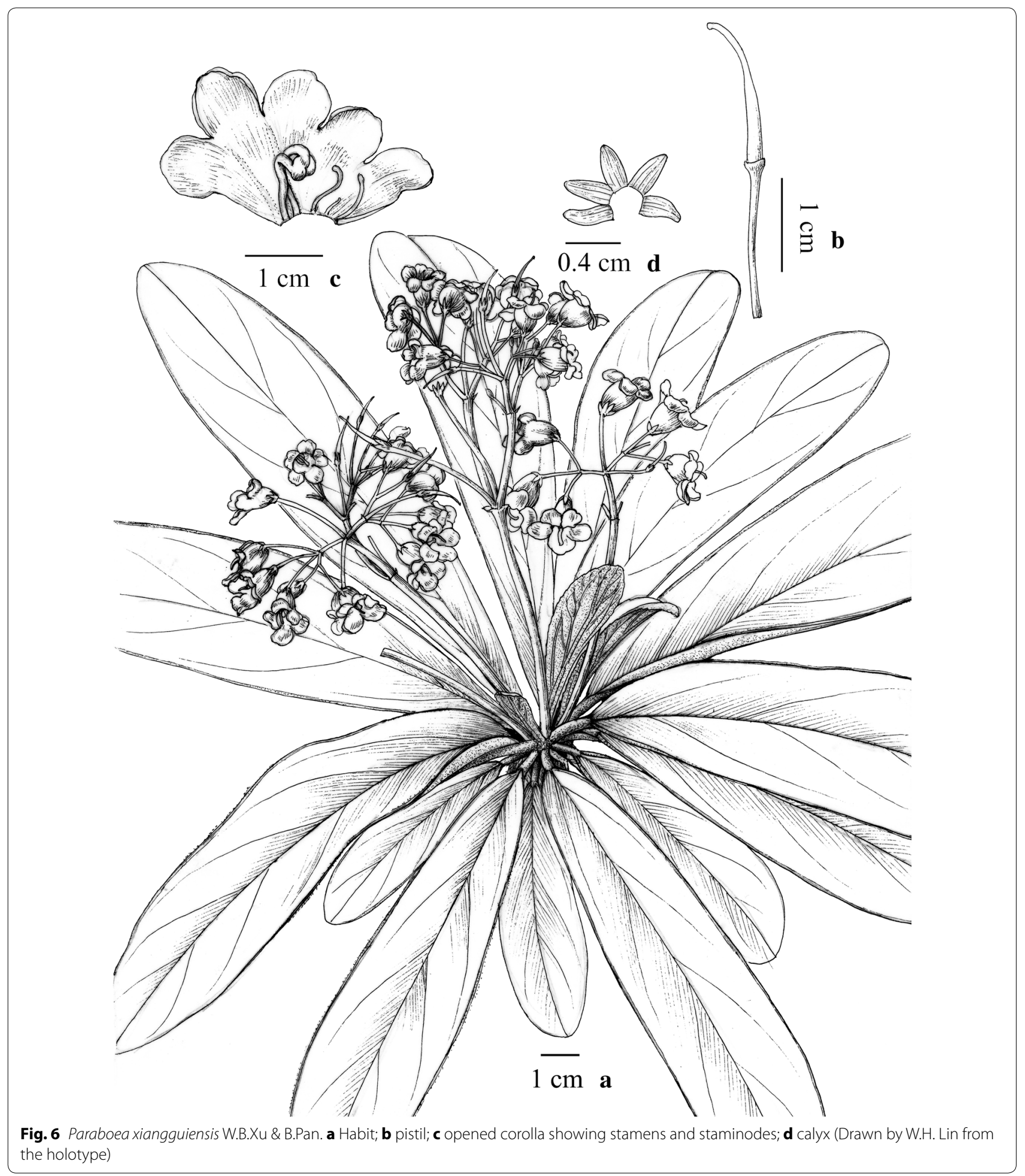

Type: CHINA. Guangxi: Jingxi County, Wuping Town. $1000 \mathrm{~m}, 23^{\circ} 12^{\prime} 39^{\prime \prime} \mathrm{N}, 106^{\circ} 30^{\prime} 56^{\prime \prime} \mathrm{E}, 1$ June 2015, Wei-Bin $X u$ et al. 12366 (holotype IBK, isotypes HAST, PE).

Perennial herbs: Rhizomes subterete, $4.5-16 \mathrm{~cm}$ long, $2-4 \mathrm{~mm}$ in diameter, erect stem short and internodes inconspicuous. Leaves $6-16$, congested at the apex of the rhizome, petiole $0.4-2.6 \mathrm{~cm}$ long, leaf blade $2.5-6 \times 0.8-$ $2.0 \mathrm{~cm}, 2-3$ times as long as wide, elliptic to long-elliptic, thickly papery to thinly leathery, bases cuneate, inequilateral, margins entire, apices obtuse, upper leaf surfaces 


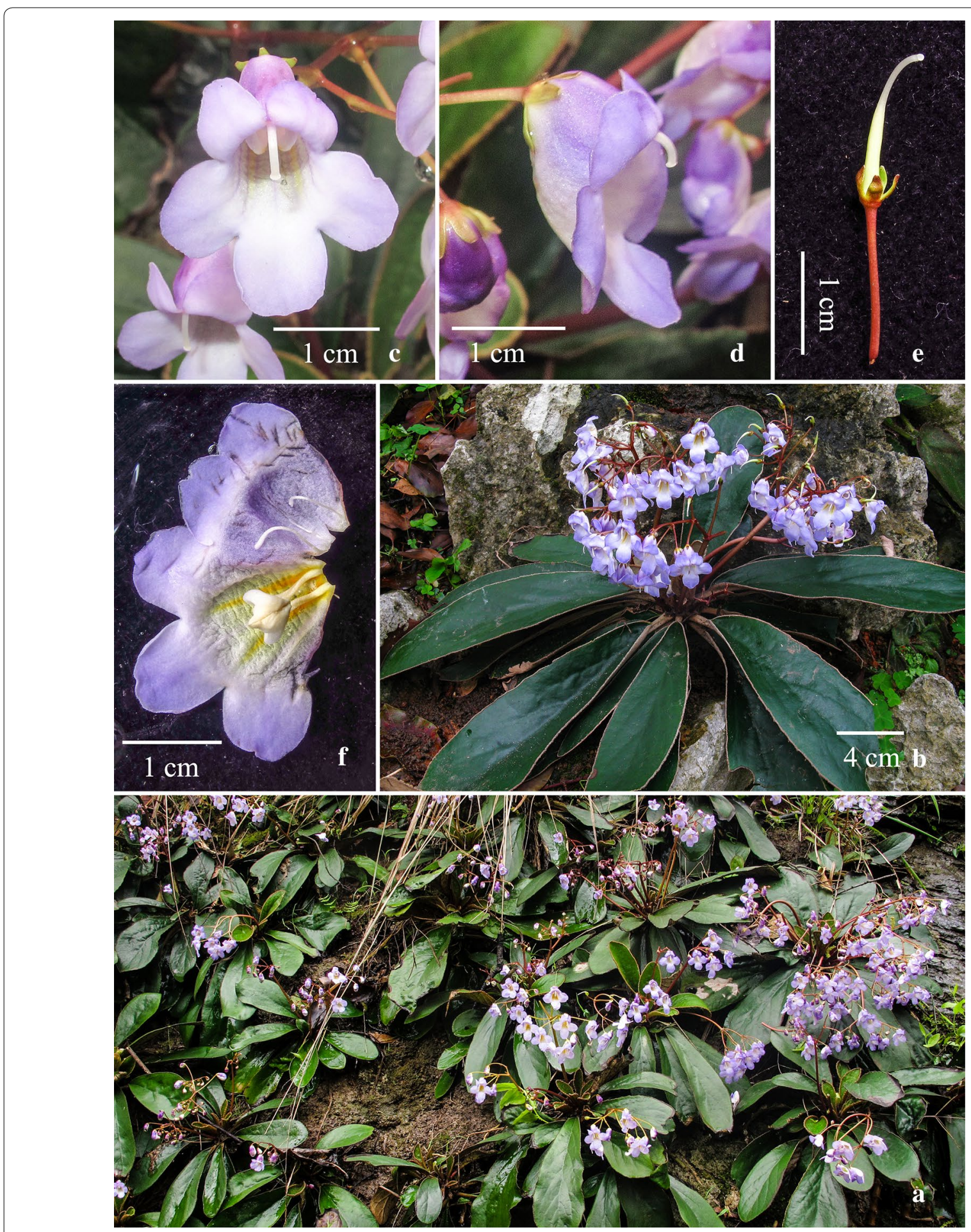

Fig. 7 Paraboea xiangguiensis W.B.Xu \& B.Pan. a Habitat; b habit; c flowers face view; d flowers side view; e pistil and calyx; f opened corolla showing stamens and staminodes

covered with arachnoid when young, but glabrescent in age, lower leaf surfaces with grayish to brownish matted indumentum, lateral veins 5-7 on each side of midrib, smooth adaxially and prominent abaxially. Inflorescences cymose, axillary, 0-1-branched, 1-3-flowered; peduncles $1-3 \mathrm{~cm}$ long, ca. $1.5 \mathrm{~mm}$ in diameter, glabrous; bracts 2 , opposite, $4-5 \times 2-3 \mathrm{~mm}$, oblong to oblongspathulate, margins entire, apices obtuse, outside and 
inside glabrous; pedicels $0.6-1.7 \mathrm{~cm}$ long, ca. $1 \mathrm{~mm}$ in diameter, glabrous. Calyx 5-9 mm long, 5-parted nearly to the base, lobes oblong-spathulate, $1.1-1.5 \mathrm{~mm}$ wide, outside and inside glabrous, margins entire, apices round. Corolla 1.5-2.3 cm long, purple-blue, outside and inside glabrous; tube $8-14 \mathrm{~mm}$ long, $8-12 \mathrm{~mm}$ in diameter at the mouth; the limb inconspicuously 2-lipped, adaxial lip 2-lobed to near base, lobes round, 5-7 $\times$ ca. $6 \mathrm{~mm}$, abaxial lip 3-lobed to over middle, lobes round, 6-8 $\times$ ca. $6 \mathrm{~mm}$. Stamens 2, adnate to the corolla base; filaments 9-12 mm long, doubly geniculate, bearded at the middle; anthers elliptic, ca. $4.0 \mathrm{~mm}$ long; staminodes 3 , glabrous, lateral ones $2-3 \mathrm{~mm}$ long, adnate to the corolla tube base, apex expanded; middle one ca. $1.5 \mathrm{~mm}$ long, adnate to the corolla tube base. Pistil glabrous; ovary 4-7 mm long, ca. $1.4 \mathrm{~mm}$ in diameter, style $5-8 \mathrm{~mm}$ long, stigma not capitate. Capsule spirally twisted, $3.0-6.5 \mathrm{~cm}$ long, ca. 2-3 $\mathrm{mm}$ in diameter, glabrous.

Distribution, habitat and ecology: Paraboea sinovietnamica is found near the border between China and Vietnam on limestone substrate, and only three populations have been identified so far by us during field investigations from 2006 to 2015 (Fig. 8). Paraboea sinovietnamica grows on rock faces of the limestone karst top, at an elevation between 400 and $1000 \mathrm{~m}$.

Phenology: This new species had been observed in flower from May to June, and fruit from July to August.

Etymology: The specific epithet is derived from the type locality, the Sino-Vietnamese border.

Notes: Paraboea sinovietnamica is most similar to $P$. sinensis (Fig. 9c, d), but it is easily distinguished from the latter by the habit, leaves, inflorescences, and flowers (see Diagnosis). Phylogenetic analyses revealed that these two species are closely related and yet considerably different from one another, supporting the recognition of $P$. sinovietnamica as a new species.

Additional specimens examined (paratypes): CHINA. Guangxi: Jingxi County, Wuping Town, 1000 m, 1 June 2015, Wei-Bin Xu et al. 12365 (IBK); ibid., 16 June 2010, Wei-Bin Xu et Yu-Song Huang. 10656 (IBK); ibid., 31 May 2006, Hai-Ning Qin et al. 531031 (PE \& IBK); ibid., 5 June 2011, Yu-Song Huang \& Dong-Xin Nong Y0624 (IBK); Ningming County, Nonggang National Nature reserve, Longrui, 430 m, 5 May 2009, Yu-Song Huang H09388 (IBK); ibid., 25 May 2008, Joint Expedition on Plants in Guangxi of CAS 1187 (IBK, KUN, PE); ibid., 14 September 2003, Wai-Chao Leong et al. 3642 (HAST); Dahua County, Yalong Twon, 800 m, 29 April 2015, Wei-Bin Xu et al. 12217 (IBK).

Paraboea xiangguiensis W.B.Xu \& B.Pan, sp. nov. 湘桂蛛毛菅苔 (Figs. 6, 7)

Diagnosis: Paraboea xiangguiensis resembles P. guilinensis L.Xu \& Y.G.Wei in the corolla shape, but differs in

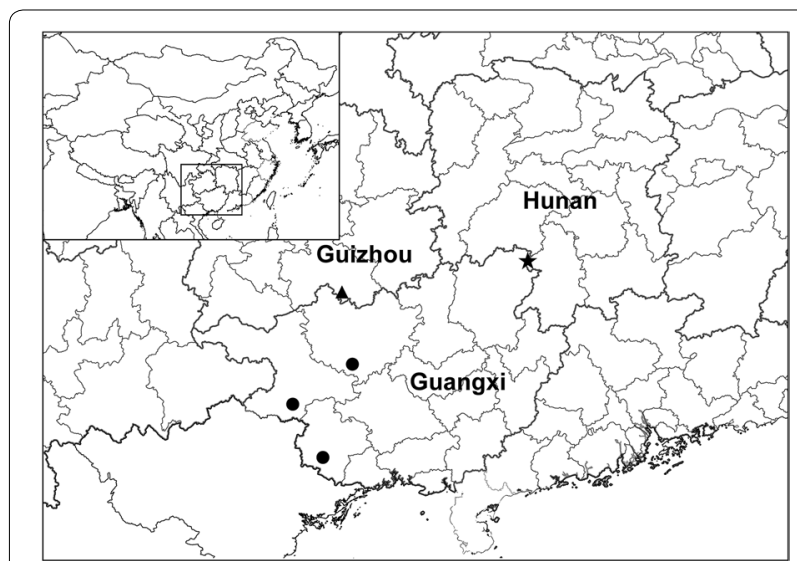

Fig. 8 Distribution of Paraboea dushanensis W.B.Xu \& M.Q.Han (triangle), Paraboea sinovietnamica W.B.Xu \& J.Guo (circle), and Paraboea xiangguiensis W.B.Xu \& B.Pan (star) in China

the rhizomes inconspicuous, $1.5-2 \mathrm{~cm}$ long, simple at the apex (vs. short caulis or conspicuous rhizomes, $2-13 \mathrm{~cm}$ long, branched or simple at the apex), the leaves subsessile or with a very short petiole up to $2 \mathrm{~cm}$ long (vs. obviously petiolate, petiole $1.4-7.0 \mathrm{~cm}$ long), the leaf blade spathulate, narrowly obovate to obovate-elliptic, $9-20 \times 2.5-4.6 \mathrm{~cm}$, base attenuate (vs. obovate-elliptic or elliptic, $2.8-5.8 \times 1.5-2.2 \mathrm{~cm}$, base rounded to broadly cuneate), the cymes, 2-3-branched, 6-22-flowered (vs. 1-2-branched, 3-8-flowered).

Type: CHINA. Guangxi: Quanzhou County, Huangshahe Town. $240 \mathrm{~m}, 26^{\circ} 03^{\prime} \mathrm{N}, 111^{\circ} 13^{\prime} \mathrm{E}, 20$ March 2013 , Wei-Bin Xu \& Bo Pan 11918 (holotype IBK, isotypes HAST, PE).

Perennial rosulate herbs: Rhizomes subterete, $1.5-2 \mathrm{~cm}$ long, ca. $10 \mathrm{~mm}$ in diameter. Leaves $8-16$, congested at the apex of the rhizome, subsessile or with a short petiole up to $2 \mathrm{~cm}$ long, leaf blade $9-20 \times 2.5-4.6 \mathrm{~cm}, 3.5-4.5$ times as long as wide, spathulate, narrowly obovate to obovate-elliptic, thickly leather, bases attenuate, margins entire to shallowly repand, apices obtuse to subround, upper leaf surfaces covered with arachnoid indumentum when young, but glabrescent at maturity, lower leaf surfaces with ferrugineous matted indumentum, lateral veins 5-7 on each side of midrib, smooth adaxially and prominent abaxially. Inflorescences cymose, axillary, 2-3-branched, 6-22-flowered; peduncles 7-13 cm long, 2-3 $\mathrm{mm}$ in diameter, glabrous; bracts 2, opposite, 2-3 × ca. $1.5 \mathrm{~mm}$, lanceolate, margins entire, apices acute, outside and inside glabrous; pedicels $0.8-2.7 \mathrm{~cm}$ long, ca. $0.6 \mathrm{~mm}$ in diameter, glabrous. Calyx 3-4 $\mathrm{mm}$ long, 5-parted nearly to the base, lobes lanceolate, $1.2-1.5 \mathrm{~mm}$ wide, outside and inside glabrous, margins entire. Corolla $1.2-2.1 \mathrm{~cm}$ long, purplish, outside and 

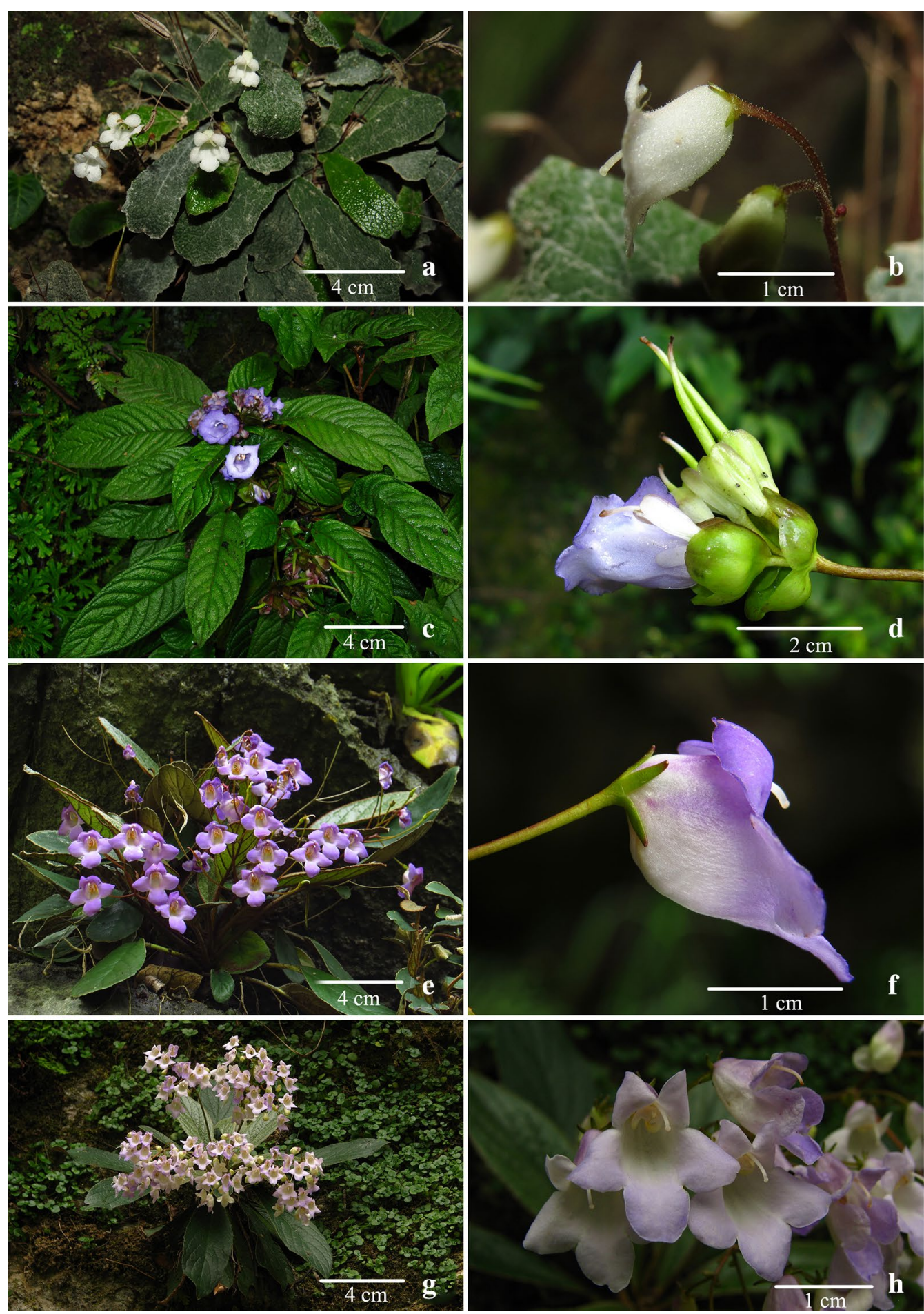

Fig. 9 Paraboea velutina (W.T.Wang \& C.Z.Gao) B.L.Burtt. a Habit; b flower side view. Paraboea sinensis (Oliv.) B.L.Burtt. c Habit; d flower side view. Paraboea guilinensis L.Xu \& Y.G.Wei. e Habit; f flower side view. Paraboea dictyoneura (Hance) B.L.Burtt. $\mathbf{g}$ Habit; $\mathbf{h}$ flowers face and side view

inside glabrous; tube $8-12 \mathrm{~mm}$ long, $8-11 \mathrm{~mm}$ in diameter at the mouth; the limb distinctly 2 -lipped, adaxial lip 2-lobed to near base, lobes broadly ovate, $5-6 \times$ ca.
$6 \mathrm{~mm}$, abaxial lip 3-lobed to over middle, lobes broadly ovate, $6-7 \times$ ca. $6 \mathrm{~mm}$. Stamens 2 , adnate to the corolla base; filaments 9-11 mm long, glabrous; anthers elliptic, 
ca. $4.0 \mathrm{~mm}$ long; staminodes 3 , glabrous, lateral ones 6-8 $\mathrm{mm}$ long, adnate to the corolla tube base, apex expanded; middle one ca. $5 \mathrm{~mm}$ long, adnate to the corolla tube base. Pistil glabrous; ovary 6-8 $\mathrm{mm}$ long, ca. $1.5 \mathrm{~mm}$ in diameter, style 6-7 mm long, stigma capitate. Dehisced fruit a slightly twisted capsule, $3.4-5.0 \mathrm{~cm}$ long, ca. 2-3 mm in diameter, glabrous.

Distribution, habitat and ecology: Paraboea xiangguiensis is only found along the border between Hunan Province and Guangxi Zhuangzu Autonomous Region on limestone substrate (Fig. 8), and only four populations have so far been identified by us during field investigations in 2013 and 2016. Paraboea xiangguiensis grows on moist rock faces of the limestone karst, at an elevation between 200 and $250 \mathrm{~m}$.

Phenology: This new species had been observed in flower from March to April.

Etymology: The specific epithet is derived from the type locality, the border between Hunan province (Abbr. Xiang) and Guangxi Zhuangzu Autonomous Region (Abbr. Gui).

Notes: Paraboea xiangguiensis is most similar to $P$. guilinensis (Fig. 9e, f) in its corolla shape, but it is easily distinguished from the latter by habit, leaves, and inflorescences (see Diagnosis). Paraboea xiangguiensis is also similar to P. dictyoneura (Fig. 9g, h), differing in leaf shape (blade spathulate, narrowly obovate to obovate-elliptic vs. narrowly obovate-elliptic), size $(9-20 \times 2.5-4.6$ vs. $7-15 \times 2-4.5 \mathrm{~cm}$ ), margins (entire to shallowly repand vs. more or less serrullate), apex (obtuse to subround vs. acute to obtuse), and hairiness of peduncle and pedicel (glabrous vs. grayish matted indumentum) and bract and calyx (glabrous outside vs. grayish matted indumentum). Phylogenetic analyses revealed that these three species are closely related and yet considerably differentiated from one another, supporting the recognition of P. xiangguiensis as a new species.

Additional specimens examined (paratypes): CHINA. Guangxi: Quanzhou County, Huangshahe Town. 220 m, 7 July 2016, Wei-Bin Xu \& Jing Guo 13006 (IBK); ibid., 7 July 2016, Wei-Bin Xu \& Jing Guo 13007 (IBK); ibid., 7 July 2016, Wei-Bin Xu \& Jing Guo 13008 (IBK); ibid., 20 March 2013, Bo Pan \& Chun-Rui Lin H2159 (IBK); ibid., 20 March 2013, Quanzhou Exped. 450324130320003LY (IBK). Hunan: Yongzhou City, Shiyantou Town, 250 m, 20 March 2013, Bo Pan et al. Y2159 (IBK).

\section{Additional file}

Additional file 1: Appendix S1.Taxon: NCBI accession numbers (ITS/trnL-F), and voucher information.
Authors' contributions

$J G, B P, M Q H, W B X$ and YL discovered the new species, WBX, YL and KFC designed the project, JG collected the molecular data, and performed the analyses. JG, WBX and KFC wrote the first draft of the manuscript. All authors read and approved the final manuscript.

\section{Author details}

${ }^{1}$ Guangxi Key Laboratory of Plant Conservation and Restoration Ecology in Karst Terrain, Guangxi Institute of Botany, Guangxi Zhuangzu Autonomous Region and Chinese Academy of Sciences, Guilin 541006, China. ${ }^{2}$ School of Life Sciences, Fudan University, Shanghai 200433, China. ${ }^{3}$ College of Life Sciences, Guangxi Normal University, Guilin 541004, China. ${ }^{4}$ Research Museum and Herbarium (HAST), Biodiversity Research Center, Academia Sinica, Taipei 11529, Taiwan.

\section{Acknowledgements}

The authors are grateful to Mr. Wen-Hong Lin for the fine line drawings, to Prof. Chun-Rui Lin (IBK) and Prof. Yu-Song Huang (IBK) for their assistance in the field, to Miss Jie Huang (IBK) for the help of molecular analysis, to two reviewers for constructive reviewers. This study was supported by the National Natural Science Foundation of China (Grant No. 31400183), and the Fund of Guangxi Key Laboratory of Plant Conservation and Restoration Ecology in Karst Terrain (16-380-32) to Wei-Bin Xu and a grant from Minister of Science and Technology, Taiwan (MOST 103-2621-B-002-004-MY3) to Kuo-Fang Chung.

\section{Competing interests}

The authors declare that they have no competing interests.

\section{Consent for publication}

Not applicable.

\section{Ethics approval and consent to participate}

Guangxi Key Laboratory of Plant Conservation and Restoration Ecology in Karst Terrain, Guangxi Institute of Botany has permits to conduct fieldtrips in Guangxi (to Wei-Bin Xu).

\section{Publisher's Note}

Springer Nature remains neutral with regard to jurisdictional claims in published maps and institutional affiliations.

Received: 3 May 2017 Accepted: 15 November 2017

Published online: 01 December 2017

\section{References}

Burtt BL (1984) Studies in the Gesneriaceae of the Old World: XLVII. Revised generic concepts for Boea and its allies. Notes R Bot Gard Edinb 41:401-452

Chen W-H, Möller M, Shui Y-M, Zhang M-D (2008) A new species of Paraboea (Gesneriaceae) from a karst cave in Guangxi, China, and observations on variations in flower and inflorescence architecture. Bot J Linn Soc 158:681-688. https://doi.org/10.1111/j.1095-8339.2008.00873.x

Chen W-H, Möller M, Zhang M-D, Shui Y-M (2012) Paraboea hekouensis and P. manhaoensis, two new species of Gesneriaceae from China. Ann Bot Fenn 49:179-187. https://doi.org/10.5735/085.049.0304

Chung K-F, Leong W-C, Rubite RR, Repin R, Kiew R, Liu Y, Peng C-I (2014) Phylogenetic analyses of Begonia sect. Coelocentrum and allied limestone species of China shed light on the evolution of Sino-Vietnamese karst flora. Bot Stud 55:e1. https://doi.org/10.1186/1999-3110-55-1

Clements R, Sodhi NS, Schilthuizen M, Ng PKL (2006) Limestone karsts of Southeast Asia: imperiled arks of biodiversity. Bioscience 56:733-742

Doyle JJ, Doyle JL (1987) A rapid DNA isolation procedure for small quantities of fresh leaf tissue. Phytochem Bull 19:11-15

Edgar RC (2004) MUSCLE: multiple sequence alignment with high accuracy and high throughput. Nucleic Acids Res 32:1792-1797. https://doi. org/10.1093/Nar/Gkh340 
Guo J, Pan B, Liu J, Xu W-B, Chung K-F (2015) Three new species of Primulina (Gesneriaceae) from limestone karsts of China based on morphological and molecular evidence. Bot Stud 56:1-13. https://doi.org/10.1186/ s40529-015-0115-5

Guo J, Lu Z-C, Liu J, Xu W-B (2016) Paraboea crassifila, a new species of Paraboea (Gesneriaceae) from Danxia landform in Guangxi, China. Taiwania 61:8-12. https://doi.org/10.6165/tai.2016.61.8

He H, Zhang L-B (2011) Polystichum cavernicola, sp. nov. (sect. Haplopolystichum, Dryopteridaceae) from a karst cave in Guizhou, China and its phylogenetic affinities. Bot Stud 52:121-127

Hou M-F, López-Pujol J, Qin H-N, Wang L-S, Liu Y (2010) Distribution pattern and conservation priorities for vascular plants in Southern China: Guangxi Province as a case study. Bot Stud 51:377-386

Kearse M, Moir R, Wilson A, Stones-Havas S, Cheung M, Sturrock S, Buxton S, Cooper A, Markowitz S, Duran C, Thierer T, Ashton B, Meintjes P, Drummond A (2012) Geneious basic: an integrated and extendable desktop software platform for the organization and analysis of sequence data. Bioinformatics 28:1647-1649. https://doi.org/10.1093/bioinformatics/ bts199

Kiew R (2010) Two new species of Paraboea (Gesneriaceae) from peninsular Malaysia and Thailand. Edinb J Bot 67:209-217. https://doi.org/10.1017/ S0960428610000107

Li Z-Y, Wang Y-Z (2004) Plants of Gesneriaceae in China. Henan Science and Technology Publishing House, Zhengzhou

Liu Y, Kono Y, Lin C-R, Xu W-B, Peng C-I (2011) Aspidistra erecta (Asparagaceae), a new species from limestone areas in Guangxi, China. Bot Stud 52:367-373

Liu J, Huang J, Xu WB, Lin CR (2016) Aspidistra ronganensis (Asparagaceae), a new species from limestone areas in Guangxi, China. Phytotaxa 270:63-68. https://doi.org/10.11646/phytotaxa.270.1.7

López-Pujol J, Zhang F-M, Sun H-Q, Ying T-S, Ge S (2011) Centres of plant endemism in China: places for survival or for speciation? J Biogeogr 38:1267-1280. https://doi.org/10.1111/j.1365-2699.2011.02504x

Middleton DJ, Puglisi C, Triboun P, Möller M (2010) Proposal to conserve Paraboea against Phylloboea and Trisepalum (Gesneriaceae). Taxon 59:1603

Möller M, Cronk QCB (1997) Origin and relationships of Saintpaulia (Gesneriaceae) based on ribosomal DNA internal transcribed spacer (ITS) sequences. Am J Bot 84:956-965

Myers N, Mittermeier RA, Mittermeier CG, da Fonseca GAB, Kent J (2000) Biodiversity hotspots for conservation priorities. Nature 403:853-858. https:// doi.org/10.1038/35002501

Peng C-I, Kuo S-M, Yang H-A, Leong W-C, Liu Y, Nguyen TH, Kono Y, Chung K-F (2014) Two new species of Begonia sect. Coelocentrum, B. guixiensis and B. longa, from Sino-Vietnamese limestone karsts. Bot Stud 55:e52. https:// doi.org/10.1186/s40529-014-0052-8

Peng C-I, Yang H-A, Kono Y, Jung M-J, Nguyen TH (2015) Four new species of Begonia (Begoniaceae) from Vietnam: B. abbreviata, B. calciphila, B. sphenantheroides and B. tamdaoensis. Phytotaxa 222:83-99. https://doi. org/10.11646/phytotaxa.222.2.1

Posada D (2008) jModelTest: phylogenetic model averaging. Mol Biol Evol 25:1253-1256. https://doi.org/10.1093/molbev/msn083

Puglisi C, Middleton DJ, Triboun P, Möller M (2011) New insights into the relationships between Paraboea, Trisepalum, and Phylloboea (Gesneriaceae) and their taxonomic consequences. Taxon 60:1693-1702

Puglisi C, Suddee S, Triboun P, Middleton DJ (2015) A new species of Paraboea (Gesneriaceae). Gard Bull Singap 67:101-106

Puglisi C, Yao TL, Milne R, Moller M, Middleton DJ (2016) Generic recircumscription in the Loxocarpinae (Gesneriaceae), as inferred by phylogenetic and morphological data. Taxon 65:277-292. https://doi.org/10.12705/652.5

Ronquist F, Teslenko M, van der Mark P, Ayres DL, Darling A, Hohna S, Larget B, Liu L, Suchard MA, Huelsenbeck JP (2012) MrBayes 3.2: efficient Bayesian phylogenetic inference and model choice across a large model space. Syst Biol 61:539-542. https://doi.org/10.1093/sysbio/sys029
Stamatakis A, Hoover P, Rougemont J (2008) A rapid bootstrap algorithm for the RAxML web servers. Syst Biol 57:758-771. https://doi. org/10.1080/10635150802429642

Taberlet P, Gielly L, Pautou G, Bouvet J (1991) Universal primers for amplification of three non-coding regions of chloroplast DNA. Plant Mol Biol 17:1105-1109

Tan Y-H, Liu Y-N, Jiang H, Zhu X-X, Zhang W, Yu S-X (2015) Impatiens pandurata (Balsaminaceae), a new species from Yunnan, China. Bot Stud 56:e29. https://doi.org/10.1186/s40529-015-0108-4

Thiers B (2017) Index Herbariorum: a global directory of public herbaria and associated staff. New York Botanical Garden's Virtual Herbarium. http:// sweetgum.nybg.org/science/ih/. Accessed 10 Oct 2017

Triboun P (2013) Paraboea middletonii (Gesneriaceae), a new species from Thailand. Thai For Bull 41:45-47

Triboun P, Middleton DJ (2012) Twenty new species of Paraboea (Gesneriaceae) from Thailand. Gard Bull Singap 64:333-370

Triboun P, Middleton DJ (2015) Three new species of Paraboea (Gesneriaceae) from Thailand. Thai For Bull 43:18-23

Wang W-T, Pan K-Y, Li Z-Y (1990) Gesneriaceae. In: Wang W-T (ed) Flora Reipublicae Popularis Sinicae, vol 69. Science Press, Beijing, pp 125-581

Wang W-T, Pan K-Y, Li Z-Y, Weitzman AL, Skog LE (1998) Gesneriaceae. In: Wu Z-Y, Raven PH (eds) Flora of China, vol 18. Science Press, Beijing, pp 244-401

Wang W, Li H-L, Chen Z-D (2014) Analysis of plastid and nuclear DNA data in plant phylogenetics —evaluation and improvement. Sci China Life Sci 57:280-286. https://doi.org/10.1007/s11427-014-4620-7

Wei Y-G (2010) Gesneriaceae of South China. Guangxi Science and Technology Publishing House, Guilin

Wei Y-G, Monro AK, Wang W-T (2011) Addition to the flora of China: seven new species of Elatostema (Urticaceae) from the karst landscapes of Guangxi and Yunnan. Phytotaxa 29:1-27

Wen F, Wei Y-G (2016) Paraboea yunfuensis: a new calcicolous species of Gesneriaceae from Yunfu, Guangdong Province, China. Telopea 19:125-129. https://doi.org/10.7751/telopea10316

Wen F, Hong X, Chen LY, Zhou SB, Wei YG (2013) A new species of Paraboea (Gesneriaceae) from a karst limestone hill in southwestern Guangdong, China. Phytotaxa 131:1-8. https://doi.org/10.11646/phytotaxa.131.1.1

Xu Z, Burtt BL, Skog LE, Middleton DJ (2008) A revision of Paraboea (Gesneriaceae). Edinb J Bot 65:161-347. https://doi.org/10.1017/ S0960428608005106

Xu W-B, Huang Y-S, Wei G-F, Tan W-N, Liu Y (2012a) Paraboea angustifolia (Gesneriaceae): a new species from limestone areas in northern Guangxi, China. Phytotaxa 62:39-43. https://doi.org/10.11646/phytotaxa.62.1.8

Xu W-B, Pan B, Liu Y, Peng C-I, Chung K-F (2012b) Two new species, Primulina multifida and P. pseudomollifolia (Gesneriaceae), from karst caves in Guangxi, China. Bot Stud 53:165-175

Xu W-B, Meng T, Zhang Q, Wu W-H, Liu Y, Chung K-F (2014) Petrocodon (Gesneriaceae) in the limestone karsts of Guangxi, China: three new species and a new combination based on morphological and molecular evidence. Syst Bot 39:965-974. https://doi.org/10.1600/036364414X681437

Yu S-X, Janssens SB, Zhu X-Y, Lidén M, Gao T-G, Wang W (2015) Phylogeny of Impatiens (Balsaminaceae): integrating molecular and morphological evidence into a new classification. Cladistics 32:179-197. https://doi. org/10.1111/cla.12119

Zhang LB, He H (2011) Polystichum fengshanense, sp. nov. (sect. Haplopolystichum, Dryopteridaceae) from Karst caves in Guangxi, China based on morphological, palynological, and molecular evidence. Syst Bot 36:854-861. https://doi.org/10.1600/036364411×604877 